http://sciforum.net/conference/ecm-1

\title{
Article
}

\section{Energy Efficient Materials for Sustainable Building}

\author{
Akin C ${ }^{1, *}$
}

1 Hindustan Institute of Technology \& Science, Hindustan University, Chennai, Tamil Nadu, India; E-Mail: akin.akin766@gmail.com

* Author to whom correspondence should be addressed; E-Mail: akin.akin766@gmail.com

Received: 22 April 2014 / Accepted: 12 May 2014 / Published: 26 May 2014

\begin{abstract}
As the population growth increases day by day building construction is also increasing. Most of the energy is consumed in buildings through various sources. One such source is the electricity. Finally it affects human health as well as wealth in lot of ways. The focus on the present paper is using the energy efficient materials such as solar cells with super capacitors and efficient lighting materials in buildings. So that the approach of the sustainable development in building is attained.
\end{abstract}

\section{Keywords:}

building; energy; solar cells; super capacitors and lighting materials.

\section{Introduction}

Each and every year constructing new buildings are increasing as the population growth goes up. Buildings consume huge quantity of electricity by the source of thermal power plants which emits heat and toxic gases like $\mathrm{Co}_{2}$. Emission of greenhouse gases and other pollutants are increasing with the increase in demand for electricity. Coal is the main source of energy for obtaining electricity in many countries. Therefore enormous amount of greenhouse gases are emitted through this source. This leads to genetic problems and defects to human health. To reduce these problems and defects, greenhouse gases should be reduced. The efficient use of coal must be reduced for generating electricity instead energy efficient materials such as solar cells, LED and super capacitors should be used. Hence this type of development makes a sustainable approach for generating electricity. 


\section{Experimental Section}

In the experimental part, a building model is taken into account. The Usual energy building [UEB] is the usual thermal energy source of building which consumes coal for generating electricity. The Energy efficient building [EEB] is the building which consumes only the energy efficient material such as solar cells, super capacitors and LED lights.

Now compare the UEB with EEB of electricity consumption and $\mathrm{Co}_{2}$ emission in a chart, therefore the energy difference can be found.



This is a $46.2 \mathrm{~m}^{2}$ building which consists of $2 \mathrm{BHK}$ [1]. The experimental part is that comparing the amount of electricity consumed in this building per month by UEB and EEB.

\section{Results and Discussion}

The present paper focuses on the energy efficient materials such as solar cells with super capacitors and efficient lighting materials in buildings with the usual thermal energy building. In this section the result of the experiment is done with the help of a chart for clear identification.

Table 1. Components of $46.2 \mathrm{~m}^{2}$ building in UEB \& EEB

\begin{tabular}{|c|l|l|}
\hline Description & \multicolumn{1}{|c|}{ UEB } & \multicolumn{1}{|c|}{ EEB } \\
\hline 2 Bed room (R) & $\begin{array}{l}\text { Florescent tube light, AC/fan, } \\
\text { computer. }\end{array}$ & $\begin{array}{l}\text { LED lights, AC.fan \& computer } \\
\text { with super capacitor }\end{array}$ \\
\hline Bathroom (B) & $\begin{array}{l}\text { Florescent lamp, electric water } \\
\text { heater. }\end{array}$ & LED lamp, solar water heater \\
\hline Kitchen (K) & $\begin{array}{l}\text { Florescent light, refrigerator, } \\
\text { washing machine \& stove. }\end{array}$ & $\begin{array}{l}\text { LED light, refrigerator, washing } \\
\text { machine with super capacitor \& } \\
\text { solar stove. }\end{array}$ \\
\hline Living room (L) & $\begin{array}{l}\text { Television, florescent lamp \& } \\
\text { AC/fan. }\end{array}$ & $\begin{array}{l}\text { LED lights, television \& AC/fan } \\
\text { with super capacitor. }\end{array}$ \\
\hline Veranda \& Terrace & Florescent tube light and lamp. & LED lamp and lights. \\
\hline
\end{tabular}


The above table shows the components of $46.2 \mathrm{~m}^{2}$ building in usual energy building and energy efficient building. The difference between UEB and EEB for the consumption of electricity is found per month of each room of $46.2 \mathrm{~m}^{2}$ building [2].

Figure 1. (a) Quantity of Electricity consumed in UEB \& EEB of $46.2 \mathrm{~m}^{2}$ building. (b) $\mathrm{Co}_{2}$ emission result for UEB \& EEB of $46.2 \mathrm{~m}^{2}$ building.

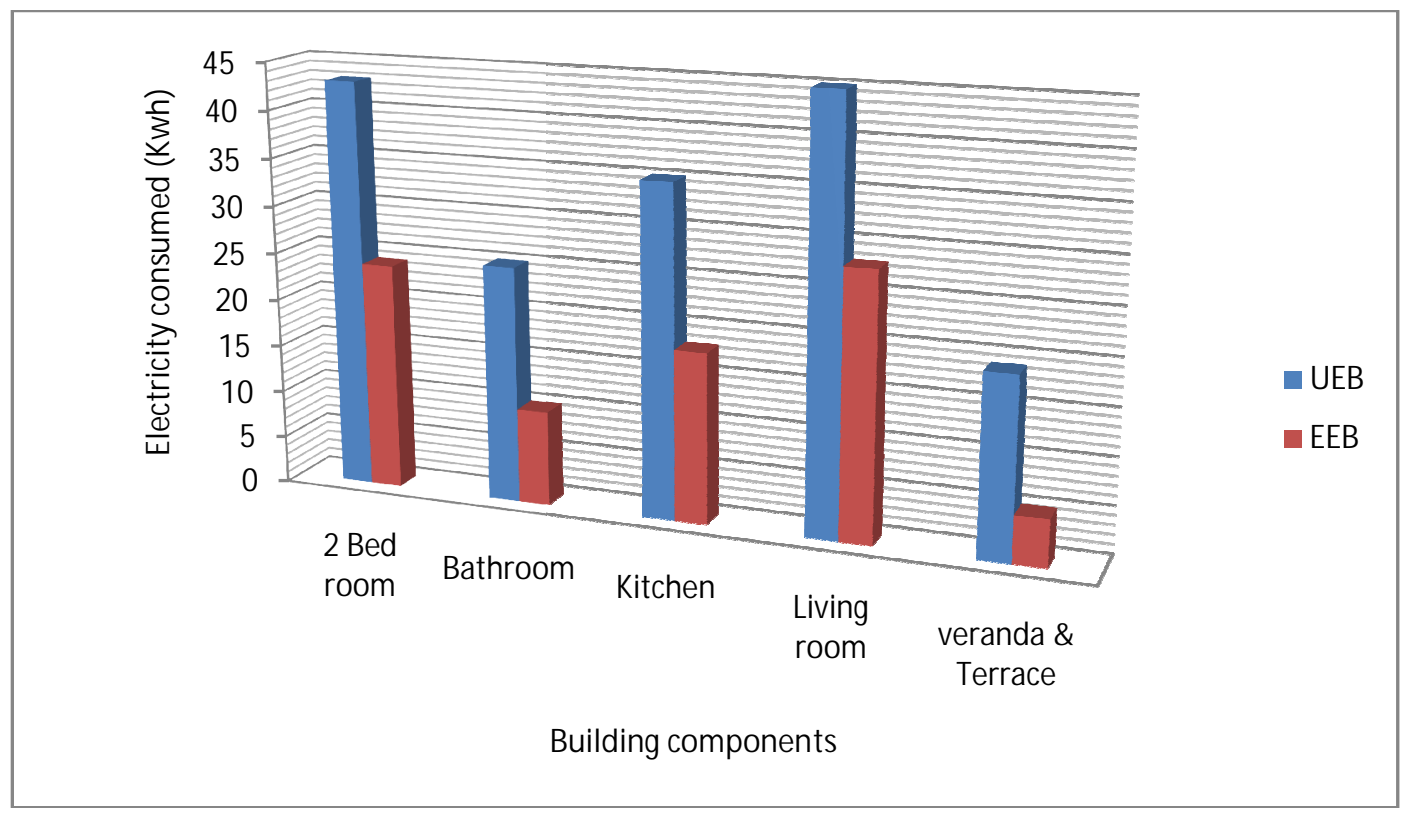

The figure 1 (a) shows that the electricity consumed in UEB is more than the electricity consumed in EEB. This results that the energy efficient materials such as solar cells, super capacitor and LED lights save enormous amount of electricity.

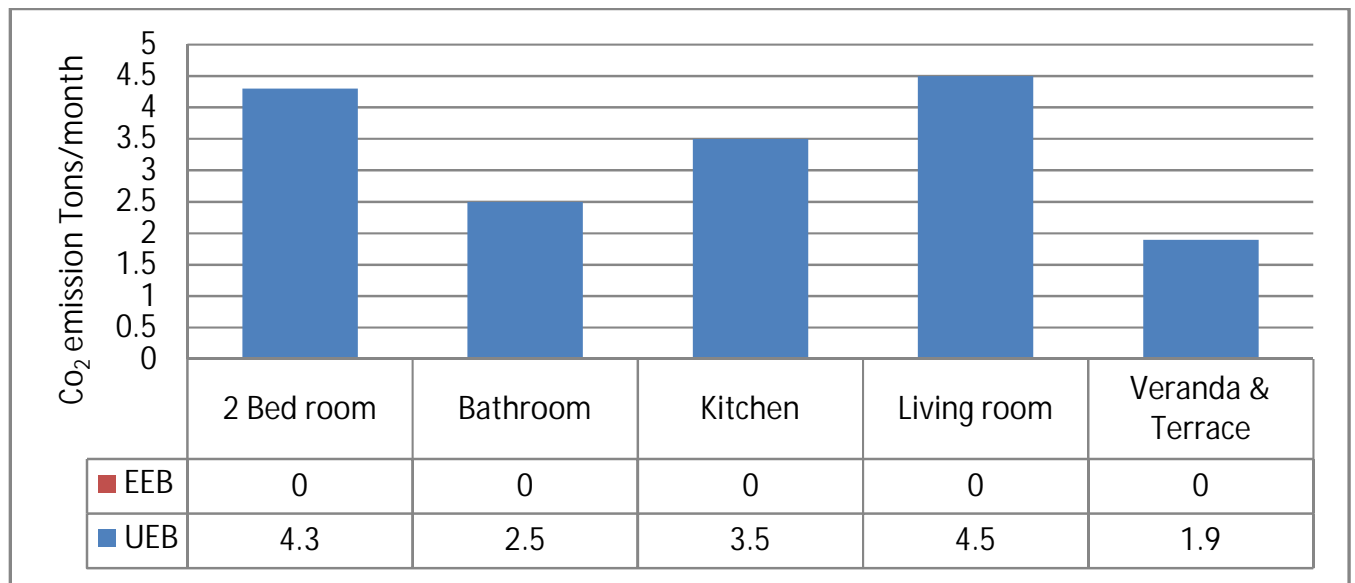

The figure 1 (b) shows the $\mathrm{Co}_{2}$ emission in $46.2 \mathrm{~m}^{2}$ building for UEB \& EEB. It shows that zero percent emission of $\mathrm{Co}_{2}$ in EEB [3]. 


\section{Conclusions}

To attain a sustainable development for buildings the energy efficient materials should be used. Therefore every building should use energy efficient materials to reduce the emission of greenhouse gases and defects for human health. The efficient use of coal must be reduced for generating electricity in thermal power plants instead of that energy efficient materials such as solar cells, LED and super capacitors should be used. Hence the conclusion of the present paper shows that the EEB saves electricity and zero percent carbon dioxide emission.

\section{Acknowledgments}

The author would like to thank Dr. Rajaraman, retired Professor of Indian Institute of Technology, madras for motivation and guidance and Department of civil engineering of Hindustan University for support.

\section{Conflicts of Interest}

The authors declare no conflict of interest.

\section{References and Notes}

1. Young-Sun Jeong; Seung-Eon Lee, Jung-Ho Huh. Estimation of $\mathrm{Co}_{2}$ emission of apartment buildings due to major construction materials in the Republic of Korea. Energy and Buildings 2012, 49, 437-442.

2. Anand, M. "Cost-Benefit Analysis of Energy Efficient Measures in Residential Construction”, M.S. Thesis, Arizona State University, 1999.

3. Geologic storage of carbon dioxide with monitoring and verification, "In Carbon dioxide Capture for storage in Deep Geologic Formations" - Results from the $\mathrm{Co}_{2}$ Capture Project, Vol. 2 (ed. Benson, S. M.), Elsevier, UK, 2005, pp. 665-672.

(C) 2013 by the authors; licensee MDPI, Basel, Switzerland. This article is an open access article distributed under the terms and conditions of the Creative Commons Attribution license (http://creativecommons.org/licenses/by/3.0/). 